Reviu Akuntansi dan Bisnis Indonesia, Vol. 1 No. 1, Hlm: 78-89, Juli 2017

Website: http://journal.umy.ac.id/index.php/rab

\title{
Pengaruh Media Exposure dan Kepemilikan Asing Terhadap Corporate Social Responsibility Expenditure dan Corporate Social Responsibility Disclosure (Studi Empiris pada Seluruh Perusahaan yang Terdaftar di Bursa Efek Indonesia Tahun 2016)
}

\author{
Septiani Pangestika; Harjanti Widiastuti \\ Program Studi Akuntansi Univeritas Muhammadiyah Yogyakarta.
}

I N F O A R T I K E L

Kata Kunci:

Corporate Social

Responsibility (CSR)

Disclosure, Corporate

Social Responsibility (CSR)

Expenditure, Kepemilikan

asing, Media Exposure.

Jenis Artikel:

Penelitian Empiris

Correspondence:

widyas@umy.ac.id

\begin{abstract}
A B S T R A K
Penelitian ini bertujuan untuk menganalisis pengaruh paparan media dan kepemilikan asing terhadap Pengeluaran Tanggung Jawab Sosial Perusahaan (CSR) dan Pengungkapan Tanggung Jawab Sosial Perusahaan (CSR). Variabel dependen dalam penelitian ini adalah Pengungkapan Corporate Social Responbility (CSR) dan Pengungkapan Corporate Social Responsibility (CSR). Variabel independen dalam penelitian ini adalah paparan media dan kepemilikan asing. Sampel dalam penelitian ini adalah 219 perusahaan yang terdaftar di Bursa Efek Indonesia 2016 yang dipilih melalui purposive sampling.Hasil penelitian menunjukkan bahwa paparan media tidak mempengaruhi Pengeluaran Corporate Social Responsibility (CSR). Kepemilikan asing berpengaruh positif terhadap Pengeluaran Tanggung Jawab Sosial Perusahaan (CSR). Paparan media secara positif dan signifikan Pengungkapan Tanggung Jawab Sosial Perusahaan (CSR). Kepemilikan asing secara positif dan signifikan mempengaruhi Pengungkapan Tanggung Jawab Sosial Perusahaan (CSR). Pengeluaran Tanggung Jawab Sosial Perusahaan (CSR) secara positif dan signifikan mempengaruhi Pengungkapan Tanggung Jawab Sosial Perusahaan (CSR).
\end{abstract}

(C) 2019 RAB. Published by Universitas Muhammadiyah Yogyakarta

\section{PENDAHULUAN}

Perusahaan yang baik adalah perusahaan yang peduli terhadap kesejahteraan lingkungan dan juga masyarakat di sekitar perusahaan itu berada. Saat ini perusahaan dituntut untuk tidak hanya berorientasi terhadap laba, tetapi juga terhadap masyarakat dan lingkungan sesuai dengan konsep triple bottom line (people, planet, profit). Perusahaan dan masyarakat merupakan suatu kesatuan yang tidak dapat dipisahkan, diantara keduanya akan selalu memberi dan membutuhkan demi kelangsungan hidup secara bersama (Dela, 2014). Tanggung jawab sosial perusahaan seperti inilah yang sering disebut dengan istilah Corporate Social Responsibility (CSR).

Kewajiban untuk melakukan CSR telah diatur di dalam Undang-Undang No.40 tahun 2007 pasal 74 tentang Perseroan Terbatas, yang menyatakan bahwa perusahaan yang menjalakankan kegiatan usahanya yang berkaitan dengan Sumber Daya Alam (SDA) wajib melaksanakan tanggung jawab sosial dan lingkungan. Perlunya CSR juga harus disadari dengan fakta bahwa sumber daya alam sangat terbatas ketersediaannya, sehingga harus dilestarikan sebagai salah satu wujud pembangunan berkelanjutan (Tamba, 2011). Meskipun peraturan mengenai Corporate Social 
Responsibility sudah diatur dalam undang-undang, masih ada perusahaan yang belum melaksanakan program tanggung jawab sosial perusahaannya, seperti yang terjadi pada salah satu perusahaan semen di Indonesia yaitu PT Semen Tonasa. PT Semen Tonasa yang berada di Makassar dianggap tidak transparan, karena masyarakat sekitar tidak mengetahui adanya anggaran yang digelontorkan untuk pengelolaan CSR. Perusahaan tersebut memberikan dana CSR hanya kepada keluarga pegawai yang bekerja pada perusahaan, sehingga keberpihakan perusahaan perlu dipertanyakan. Padahal masyarakat sekitar selalu memperoleh polusi udara dan kebisingan saat pabrik beroperasi (sumber: republika.co.id). Hal itu menunjukkan kesuksesan yang diperoleh perusahaan tidak disertai dengan kepedulian terhadap masyarakat dan lingkungan. Namun, banyak perusahaan yang telah melaksanakan program CSR dengan baik. Salah satunya adalah perusahaan air mineral yaitu Aqua. Dengan programnya yang berjudul 1L Aqua untuk 10L Air Bersih, perusahaan tersebut mengupayakan program air bersih bagi masyarakat di Nusa Tenggara Timur, karena di daerah tersebut masyarakat sangat sulit untuk mendapatkan air bersih. Aqua merupakan perusahaan penghasil air mineral tersohor di Indonesia, sehingga perusahaan mempunyai profit yang cukup tinggi. Dengan keuntungan yang tinggi tersebut, Aqua menggelontorkan dana hingga mencapai Rp 12 triliun setiap tahunnya untuk menjalankan program CSR.

Pengungkapan CSR saat ini masih menjadi kegiatan yang bersifat sukarela, namun perusahaan yang telah melakukan kegiatan CSR akan melakukan berbagai cara untuk mengungkapkannya agar masyarakat mengetahui bahwa perusahaan telah melaksanakan praktik CSR. Salah satu cara yang dilakukan adalah dengan mengungkapkan melalui media website perusahaan. Tujuan dari pengungkapan ini untuk memberikan informasi terkait perusahaan, yang diharapkan akan memperoleh citra yang baik dari masyarakat. Karena dengan pengungkapan ini masyarakat akan menganggap perusahaan secara transparansi mengungkapkan aktivitas atau kegiatannya.

Semakin banyak CSR Expenditure maka semakin banyak pula aktivitas CSR yang diungkapkan oleh perusahaan. Namun ini berarti perusahaan banyak berkontribusi terhadap kegiatan sosial dan kepedulian terhadap lingkungan. CSR Expenditure merupakan biaya-biaya yang dikeluarkan oleh perusahaan untuk melaksanakan aktivitas yang berkaitan dengan CSR.

Pengungkapan tanggung jawab sosial antar perusahaan dapat berbeda karena adanya variasi praktik CSR. Perbedaan tingkat pengungkapan CSR tersebut ditunjukkan oleh data tabel 1:

Tabel 1 Tingkat CSR Disclosure perusahaan-perusahaan di Indonesia

\begin{tabular}{|c|c|c|c|c|}
\hline No & Peneliti & Sampel Penelitian & $\begin{array}{c}\text { Periode } \\
\text { Penelitian }\end{array}$ & $\begin{array}{c}\text { Rata-rata } C S R \\
\text { Disclosure }\end{array}$ \\
\hline 1 & Alfarizi (2016) & $\begin{array}{l}\text { Perusahaan Manufaktur } \\
\text { yang Terdaftar di BEI }\end{array}$ & 2013-2015 & $27,38 \%$ \\
\hline 2 & $\begin{array}{l}\text { Febrianti } \\
(2016)\end{array}$ & $\begin{array}{l}\text { Perusahaan Sektor } \\
\text { Pertambangan yang } \\
\text { Terdaftar di BEI }\end{array}$ & 2011-2015 & $29,86 \%$ \\
\hline 3 & $\begin{array}{l}\text { Wahyutama } \\
(2016)\end{array}$ & $\begin{array}{l}\text { Perusahaan Industri } \\
\text { Dasar dan Kimia yang } \\
\text { Terdaftar di BEI }\end{array}$ & 2011-2014 & $19,45 \%$ \\
\hline 4 & $\begin{array}{l}\text { Rahayu dan } \\
\text { Anisyukurlillah } \\
\text { (2015) }\end{array}$ & $\begin{array}{l}\text { Perusahaan Properti dan Real } \\
\text { Estate yang } \\
\text { Terdaftar di BEI }\end{array}$ & 2011-2013 & $25,56 \%$ \\
\hline 5 & Dela (2014) & $\begin{array}{l}\text { Perusahaan Manufaktur } \\
\text { yang Terdaftar di BEI }\end{array}$ & 2008-2012 & $16,24 \%$ \\
\hline 6 & $\begin{array}{l}\text { Priantana } \\
(2011)\end{array}$ & $\begin{array}{l}\text { Perusahaan Keuangan } \\
\text { yang Terdaftar di BEI }\end{array}$ & 2007-2008 & $18,33 \%$ \\
\hline
\end{tabular}

Berdasarkan data pada tabel 1, menunjukkan bahwa CSR Disclosure bervariasi dari tahun ke tahun dan antar industri. CSR Disclosure masih relatif rendah dengan rata-rata disclosure $<50 \%$. Beberapa faktor diduga mempengaruhi luas pengungkapan CSR diantaranya meliputi: (1) Media Exposure (Handoko, 2017; Alfarizi, 2016; Wahyutama, 2016; Rahayu dan Anisyukurlillah, 2015; 
Plorensia dan Hardiningsih, 2015), dan (2) Kepemilikan Asing (Alfarizi, 2016; Yuliani, 2014; Laksmitaningrum, 2013; Tamba, 2011; Rustiarini, 2011).

Menurut Patten (2002) dalam Reverte (2009), media memiliki fungsi yang penting untuk memobilisasi pergerakan sosial, misalnya kelompok-kelompok yang tertarik terhadap masalah lingkungan. Pemberitaan media akan mendorong perusahaan untuk lebih memperhatikan masalah lingkungan dan lebih banyak melakukan pengungkapan CSR, tujuannya agar perusahaan mendapatkan penilaian positif dari masyarakat. Penelitian yang dilakukan oleh Plorensia dan Hardiningsih (2015), Alfarizi (2016), Wahyutama (2016) dan Handoko (2017) menunjukkan bahwa media exposure mempunyai pengaruh terhadap pengungkapan CSR. Namun, Rahayu dan Indah (2015) dalam penelitiannya menemukan bahwa media exposure tidak berpengaruh terhadap pengungkapan CSR.

Pelaksanaan aktivitas Corporate Social Responbility tidak bisa terlepas dari penerapan Good Corporate Governance (GCG). Salah satu faktor GCG yang berpengaruh terhadap pelaksanaan CSR adalah kepemilikan asing (Rustiarini, 2011). Kepemilikan asing dapat diartikan sebagai jumlah kepemilikan saham yang dimiliki oleh pihak yang berstatus luar negeri. Perusahaan yang berbasis asing mempunyai teknologi yang berkualitas, keterampilan karyawan yang baik serta

jaringan informasi yang luas, sehingga memungkinkan perusahaan untuk melakukan pengungkapan yang lebih luas (Tamba, 2011). Penelitian terdahulu yang dilakukan oleh Rustiarini (2011) dan Tamba (2011) menunjukkan bahwa kepemilikan asing mempunyai pengaruh terhadap pengungkapan CSR, sejalan dengan penelitian yang dilakukan oleh Laksmitaningrum (2013) dan Alfarizi (2016) yang menemukan adanya pengaruh kepemilikan asing terhadap pengungkapan CSR. Penelitian selanjutnya yang dilakukan oleh Yuliani (2014) menunjukkan kepemilikan asing tidak berpengaruh terhadap pengungkapan CSR.

\section{TINJAUAN LITERATUR DAN PERUMUSAN HIPOTESIS}

\section{Teori Legitimasi}

Teori legitimasi menjelaskan bahwa suatu bisnis dibatasi oleh kontrak sosial, dimana suatu perusahaan setuju untuk melaksanakan aktivitas sosialnya yang bertujuan untuk memperoleh kepercayaan dari masyarakat (Reverte, 2009). Dengan adanya kepercayaan dari masyarakat dapat membantu perusahaan untuk mencapai tujuannya, oleh karena itu perusahaan perlu menyelaraskan nilai-nilai perusahaan dengan norma yang berlaku dimasyarakat. Kepedulian perusahaan terhadap masyarakat dan lingkungannya akan turut serta dalam meningkatkan legitimasi dari masyarakat. Penerimaan perusahaan di tengah-tengah masyarakat akan menjamin keberlanjutan perusahaan di masa yang akan datang, karena masyarakat percaya bahwa perusahaan dalam melakukan segala aktivitasnya dibatasi oleh norma-norma yang berlaku di dalam masyarakat.

\section{Teori Stakeholder}

Keberlangsungan hidup perusahaan pada dasarnya bergantung pada dukungan dari stakeholder. Oleh karena itu, perusahaan harus menjaga hubungannya dengan stakeholder. Menurut Putra (2011), cara agar dapat menjaga hubungan dengan stakeholder adalah dengan melakukan atau mengungkapkan CSR. Dengan adanya kegiatan CSR keinginan dari para stakeholder agar perusahaan peduli terhadap sosial dan lingkungan dapat tercapai, sehingga dapat menciptakan hubungan harmonis antara perusahaan dengan masyarakat atau pemangku kepentingan.

\section{Teori Pensinyalan}

Teori sinyal dapat digunakan untuk mengurangi asimetri informasi yang muncul dari pihak pemilik perusahaan maupun luar perusahaan. Semua informasi yang bersifat keuangan ataupun 
non keuangan harus diungkapkan oleh perusahaan, termasuk informasi mengenai CSR karena informasi tersebut dapat berguna dalam pengambilan keputusan. Bagi perusahaan yang telah melaksanakan praktik CSR pasti menginginkan agar masyarakat mengetahuinya, cara yang dapat dilakukan adalah dengan melakukan pengungkapan. Pengungkapan CSR ini akan memberikan efek positif bagi perusahaan, karena dapat memberikan sinyal kepada masyarakat bahwa perusahaan memiliki prospek yang baik di masa depan.

\section{Corporate Social Responsibility (CSR)}

The World Council for Sustainable Development mendefinisikan CSR sebagai komitmen dari perusahaan untuk berkontribusi bagi pembangunan ekonomi yang berkelanjutan untuk meningkatkan kualitas kehidupan sehingga berdampak baik bagi bisnis sekaligus baik bagi kehidupan sosial. Semua perusahaan yang kegiatannya berkaitan dengan sumber daya alam wajib untuk melaksanakan praktik CSR sesuai dengan peraturan perundang-undangan sebagai wujud kepeduliannya terhadap lingkungan sekitar. Dalam melakukan CSR, perusahaan mengeluarkan biaya-biaya untuk menjalankan kegiatannya yang dikenal dengan istilah CSR Expenditure. Biayabiaya ini lah yang mencerminkan banyaknya kegiatan CSR yang dilakukan oleh perusahaan. Jadi, semakin banyak jumlah CSR Expenditure maka kegiatan CSR yang dilakukan oleh perusahaan semakin banyak (Febrianti, 2016).

\section{Pengaruh Media Exposure Terhadap CSR Expenditure dan CSR Disclosure}

Dalam penelitian ini media exposure didefinisikan sebagai seberapa besar suatu perusahan disorot oleh media. Pemberitaan suatu perusahan di media mempunyai peran penting dalam kaitannya dengan citra perusahaan. Apabila pemberitaan itu positif maka perusahaan akan memperoleh citra yang baik dari masyarakat, namun sebaliknya apabila pemberitaan itu negatif maka perusahaan akan memperoleh citra yang buruk.

Salah satu cara yang dapat dilakukan oleh perusahaan agar mendapatkan citra yang baik dari masyarakat adalah dengan meningkatkan kepeduliannya terhadap sosial dan lingkungan. Hal tersebut berkaitan dengan teori stakeholder, dimana suatu perusahaan dapat menjaga keberlangsungan hidup perusahan yang bergantung dari stakeholdernya. Oleh karena itu perusahaan harus menjaga hubungannya dengan para stakeholder. Pemberitaan di media juga akan mendorong perusahaan untuk lebih banyak melakukan pengungkapan kegiatannya, salah satunya adalah CSR. Tujuannya adalah untuk menghindari konflik yang mungkin saja muncul karena masalah sosial dan lingkungan.

Penelitian yang dilakukan oleh Plorensia dan Hardiningsih (2015) dengan sampel perusahaan pertambangan yang terdaftar di Bursa Efek Indonesia pada tahun 2011 sampai 2014 menemukan adanya pengaruh positif signifikan media exposure terhadap pengungkapan Corporate Social Responbility. Sejalan dengan penelitian Plorensia dan Hardiningsih (2015), Alfarizi (2016) dan Handoko (2017) juga menemukan pengaruh positif variabel media exposure terhadap pengungkapan tanggung jawab sosial. Berdasarkan uraian tersebut, dapat disimpulkan hipotesis sebagai berikut:

\section{$\boldsymbol{H}_{l a} \quad$ : Media exposure berpengaruh positif terhadap CSR Expenditure \\ $\boldsymbol{H}_{I b} \quad$ : Media exposure berpengaruh positif terhadap CSR Disclosure}

\section{Pengaruh Kepemilikan Asing Terhadap CSR Expenditure dan CSR Disclosure}

Kepemilikan asing merupakan jumlah seluruh saham yang dimiliki secara individu maupun lembaga yang berstatus asing (luar negeri) terhadap saham perusahaan di Indonesia. Perusahaan dengan kepemilikan saham asing biasanya lebih sering mengalami asimetri informasi karena 
keterbatasan bahasa dan letak geografis. Oleh karena itu perusahaan yang berbasis asing akan mendorong pihak manajemen untuk mengungkapkan informasinya secara lebih luas.

Kepemilikan saham asing juga memiliki hubungan dengan CSR Expenditure, karena pemilik asing sangat memperhatikan isu sosial seperti hak asasi manusia, pendidikan dan tenaga kerja (Diana, 2016). Oleh karena itu, kepemilkian asing cenderung mengalokasikan biaya yang lebih besar untuk meningkatkan praktik CSR.

Laksmitaningrum (2013) dalam penelitiannya menunjukkan kepemilikan asing memiliki pengaruh positif terhadap pengungkapan Corporate Social Responsibility dengan sampel perusahaan manufaktur yang terdaftar di Bursa Efek Indonesia tahun 2009 sampai 2011. Hasil penelitian tersebut konsisten dengan penelitian Rustiarini (2011) dengan sampel perusahaan manufaktur yang terdaftar di Bursa Efek Indonesia tahun 2008 yang menemukan pengaruh positif kepemilikan asing terhadap pengungkapan Corporate Social Responsibility. Berdasarkan penjelasan diatas dapat disimpulkan hipotesis sebagai berikut:

\section{$\boldsymbol{H}_{2 .} \quad$ : Kepemilikan asing berpengaruh positif terhadap CSR Expenditure \\ $\boldsymbol{H}_{2 b} \quad$ : Kepemilikan asing berpengaruh positif terhadap CSR Disclosure}

\section{Pengaruh CSR Expenditure Terhadap CSR Disclosure}

CSR Expenditure adalah biaya-biaya yang dikeluarkan oleh perusahaan untuk melaksanakan aktivitas yang berkaitan dengan CSR. Banyaknya biaya yang dikeluarkan oleh perusahaan dapat mencerminkan kegiatan CSR yang dilakukan, sehingga semakin banyak kegiatan CSR yang dilakukan, semakin banyak pula jumlah CSR Expenditure (Febrianti, 2016).

Banyaknya biaya yang dikeluarkan oleh perusahaan juga akan mendorong perusahaan untuk meningkatkan pengungkapan CSR nya. Apabila dikaitkan dengan teori signalling, pengungkapan CSR ini akan memberikan sinyal kepada masyarakat bahwa perusahaan memiliki kinerja yang baik, sehingga masyarakat akan memberikan citra yang baik terhadap perusahaan. Citra yang baik tidak hanya mengurangi rumor negatif, tetapi juga berkontribusi untuk menarik pelanggan. Berdasarkan penjelasan tersebut dapat disimpulkan hipotesis sebagai berikut:

\section{$\mathrm{H}_{3} \quad$ : CSR Expenditure berpengaruh positif terhadap CSR Disclosure}

\section{METODE PENELITIAN}

Obyek pada penelitian ini adalah seluruh perusahaan yang terdaftar di Bursa Efek Indonesia tahun 2016. Alasan peneliti menggunakan seluruh perusahaan adalah untuk melihat variasi pengungkapan CSR di Indonesia dari berbagai sektor industri. Pengambilan data dalam penelitian ini menggunakan metode dokumentasi dan content analysis. Sampel yang diambil dalam penelitian ini dengan menggunakan teknik purposive sampling yaitu pengambilan sampel dengan sejumlah kriteria tertentu. Kriteria sampel dalam penelitian ini adalah:

1. Perusahaan menerbitkan laporan tahunan pada tahun 2016.

2. Perusahaan memiliki informasi mengenai CSR.

3. Perusahaan memiliki kepemilikan asing.

4. Definisi Operasional Variabel Penelitian

Penelitian ini menggunakan uji regresi linear berganda untuk menguji pengaruh variabel independen terhadap variabel dependen. Dalam penelitian ini menggunakan variabel independen media exposure dan kepemilikan asing. Sedangkan variabel dependennya adalah CSR expenditure dan CSR disclosure. 
Hipotesis H1a dan $\mathrm{H} 2 \mathrm{a}$ akan diuji dengan persamaan regresi 1, yaitu:

$\mathrm{CSRE}=\alpha+\beta 1 M E+\beta 2 A S I N G+e$

Adapun hipotesis $\mathrm{H} 1 \mathrm{~b}, \mathrm{H} 2 \mathrm{~b}$ dan $\mathrm{H} 3$ akan diuji dengan persamaan regresi 2, yaitu:

$\mathrm{CSRD}=\alpha+\beta 1 M E+\beta 2 A S I N G+\beta 3 C S R E+e$

Keterangan:

$\begin{array}{ll}\text { CSRE } & : \text { CSR Expenditure } \\ \text { CSRD } & : \text { CSR Disclosure } \\ \alpha & : \text { konstanta } \\ \beta & : \text { koefisien regresi variable independen } \\ \text { ME } & : \text { media exposure } \\ \text { ASING } & : \text { kepemilikan asing } \\ \text { e } & : \text { standard error }\end{array}$

\section{HASIL DAN PEMBAHASAN}

\section{Gambaran Umum Objek Penelitian}

Tabel 2 Prosedur Pemilihan Sampel

\begin{tabular}{lc}
\hline \multicolumn{1}{c}{ Kriteria Sampel } & Jumlah \\
\hline Perusahaan yang terdaftar di BEI tahun 2016 & 560 \\
Perusahaan yang tidak menerbitkan Annual Report & $(82)$ \\
Perusahaan yang tidak memiliki kepemilikan asing & $(136)$ \\
Perusahaan yang tidak mengungkapkan CSR & $(34)$ \\
Disclosure & \\
Perusahaan yang tidak mengungkapkan CSR & $(46)$ \\
Expenditure & \\
Perusahaan yang mengalami kerugian & $(43)$ \\
Perusahaan yang menjadi sampel & 219 \\
\hline
\end{tabular}

Uji statistik deskriptif memberikan gambaran penelitian ini mengenai nilai minimum, nilai maksimum, nilai rata-rata (mean), median dan simpangan baku (standar deviation) dari variabel independen dan variabel dependen. Berikut ini tabel statistik deskriptif CSR Expenditure dan CSR Disclosure :

Tabel 3 Statistik Deskriptif CSR Expenditure dan CSR Disclosure

\begin{tabular}{lrrrrrr}
\hline Variabel & N & \multicolumn{1}{c}{ Min } & \multicolumn{1}{c}{ Max } & \multicolumn{1}{c}{ Mean } & \multicolumn{1}{c}{ Std. Deviation } & \multicolumn{1}{c}{ Median } \\
\hline ME & 219 & 0 & 39 & 2,51 & 4,096 & 1 \\
ASING & 219 & 0,0005 & 0,9980 & 0,385747 & 0,2992971 & 0,3161 \\
CSRE & 219 & 0,0001 & 0,9487 & 0,049036 & 0,1083484 & 0,0100 \\
CSRD & 219 & 0,0440 & 0,5165 & 0,215914 & 0,0856459 & 0,2088 \\
Valid N & 219 & & & & & \\
(listwise) & & & & & & \\
\hline
\end{tabular}


Tabel 4 Nilai Rata-Rata CSR Expenditure dan CSR Disclosure Per Sektor Industri

\begin{tabular}{lcc}
\hline \multicolumn{1}{c}{ Industri } & Mean & Mean \\
& CSRE & CSRD \\
\hline Pertanian & 0,0187 & 0,2619 \\
Pertambangan & 0,1151 & 0,3469 \\
Industri Dasar \& Kimia & 0,0739 & 0,2096 \\
Aneka Industri & 0,0218 & 0,1884 \\
Barang Konsumsi & 0,0373 & 0,2659 \\
Properti, Real Estate \& Konstruksi & 0,0552 & 0,1890 \\
Bangunan & 0,0330 & 0,1984 \\
Infrastruktur, Utilitas \& Transportasi & 0,0503 & 0,1998 \\
Keuangan & 0,0506 & 0,1917 \\
\hline Perdagangan, Jasa \& Investasi & & \\
\hline
\end{tabular}

Uji Asumsi Klasik

Uji Normalitas

Tabel 5 Hasil Uji Normalitas

\begin{tabular}{lcccc}
\hline \multicolumn{1}{c}{ Model } & $\mathbf{N}$ & $\begin{array}{c}\text { Kolmogorov } \\
\text {-Smirnov }\end{array}$ & $\begin{array}{c}\text { Asymp.Sig. (2- } \\
\text { tailed) }\end{array}$ & Kesimpulan \\
\hline $\begin{array}{l}\text { CSR } \\
\text { Expenditure }\end{array}$ & 219 & 0,463 & 0,983 & Berdistribusi Normal \\
$\begin{array}{l}\text { CSR } \\
\text { Disclosure }\end{array}$ & 219 & 0,583 & 0,886 & Berdistribusi Normal \\
\hline
\end{tabular}

Uji Multikolinearitas

Tabel 6 Hasil Uji Multikolinearitas

\begin{tabular}{llrrl}
\hline \multicolumn{1}{c}{ Model } & Variabel & Tolerance & VIF & Kesimpulan \\
\hline CSR & ME & 0,955 & 1,047 & Non Multikolinearitas \\
Expenditure & ASING & 0,955 & 1,047 & Non Multikolinearitas \\
CSR & ME & 0,955 & 1,047 & Non Multikolinearitas \\
Disclosure & ASING & 0,936 & 1,068 & Non Multikolinearitas \\
& CSRE & 0,979 & 1,021 & Non Multikolinearitas \\
\hline
\end{tabular}

\section{Uji Heteroskesdastisitas}

Tabel 7 Hasil Uji Heteroskesdastisitas

\begin{tabular}{llcc}
\hline \multicolumn{1}{c}{ Model } & Variabel & Sig. & Keterangan \\
\hline CSR & ME & 0,335 & Homoskesdastisitas \\
Expenditure & ASING & 0,710 & Homoskesdastisitas \\
CSR & ME & 0,685 & Homoskesdastisitas \\
Disclosure & ASING & 0,950 & Homoskesdastisitas \\
& CSRE & 0,405 & Homoskesdastisitas \\
\hline
\end{tabular}




\section{Hasil Pengujian Hipotesis}

Tabel 8 Hasil Pengujian Hipotesis Model CSR Expenditure

\begin{tabular}{|c|c|c|c|c|}
\hline Variabel & $\begin{array}{c}\text { Koefisien } \\
\text { Regresi }\end{array}$ & Nilai t & Nilai Sig. & Kesimpulan \\
\hline Constant & $-4,311$ & $-16,208$ & 0,000 & \\
\hline Media Exposure & 0,019 & 0,082 & 0,935 & Tidak didukung \\
\hline Kepemilikan & 0,184 & 2,086 & 0,038 & Didukung \\
\hline Asing & & & & \\
\hline Adjusted R2 & 0,012 & & & \\
\hline F Statistik & 2,320 & & & \\
\hline Sig. & 0,101 & & & \\
\hline
\end{tabular}

Tabel 9 Hasil Pengujian Hipotesis Model CSR Disclosure

\begin{tabular}{|c|c|c|c|c|}
\hline Variabel & $\begin{array}{c}\text { Koefisien } \\
\text { Regresi }\end{array}$ & Nilai t & Nilai Sig. & Kesimpulan \\
\hline Constant & $-1,460$ & $-20,935$ & 0,000 & \\
\hline Media Exposure & 0,204 & 5,033 & 0,000 & Didukung \\
\hline Kepemilikan & 0,038 & 2,426 & 0,016 & Didukung \\
\hline Asing & & & & \\
\hline CSR & 0,047 & 3,917 & 0,000 & Didukung \\
\hline Expenditure & & & & \\
\hline Adjusted R2 & 0,202 & & & \\
\hline F Statistik & 19,441 & & & \\
\hline Sig. & 0,000 & & & \\
\hline
\end{tabular}

\section{Uji Simultan (Uji F)}

Tabel 8 menunjukkan bahwa model CSR Expenditure memiliki nilai F sebesar 2,320 dengan nilai sig $0,101>$ alpha 0,05 . Artinya variabel independen (media exposure dan kepemilikan asing) tidak berpengaruh secara simultan atau secara bersama-sama terhadap variabel CSR Expenditure. Sedangkan berdasarkan tabel 9 pengujian untuk model CSR Disclosure mendapatkan hasil nilai F sebesar 19,441 dengan nilai sig $0,000<$ alpha 0,05 artinya variabel media exposure, kepemilikan asing dan CSR Expenditure secara bersama-sama berpengaruh terhadap variabel CSR Disclosure.

\section{Uji Parsial (Uji t)}

\section{Pengujian $\mathrm{H}_{\mathrm{la}}$ dan $\mathrm{H}_{\mathrm{b}}$}

Berdasarkan tabel 8 untuk melihat pengaruh variabel media exposure terhadap CSR Expenditure memiliki nilai koefisien regresi sebesar 0,019 dengan arah positif dan nilai sig 0,935 lebih besar dari alpha 0,05 artinya variabel media exposure tidak berpengaruh terhadap CSR Expenditure. Hal ini tidak sesuai dengan hipotesis yang menyatakan bahwa media exposure berpengaruh terhadap CSR Expenditure. Maka dapat diambil kesimpulan hipotesis H1a ditolak.

Kemudian untuk melihat pengaruh variabel media exposure terhadap variabel CSR Disclosure dapat dilihat pada tabel 9 Variabel media exposure memiliki nilai koefisien regresi sebesar 0,204 dengan arah positif dan nilai sig 0,000 lebih kecil dari alpha 0,05 artinya variabel media exposure berpengaruh positif terhadap CSR Disclosure. Dengan demikian, dapat diambil kesimpulan bahwa hipotesis H1b diterima. 


\section{Pengujian $\mathbf{H}_{2 \mathrm{a}}$ dan $\mathrm{H}_{2 \mathrm{~b}}$}

Berdasarkan tabel 8 yang digunakan untuk melihat pengaruh variabel kepemilikan asing terhadap variabel CSR Expenditure, memiliki nilai koefisien regresi sebesar 0,184 dengan arah positif dan nilai sig sebesar 0,038 lebih kecil dari alpha 0,05. Hal ini menunjukkan bahwa variabel kepemilikan asing berpengaruh positif terhadap variabel CSR Expenditure. Maka dapat ditarik kesimpulan hipotesis H2a diterima.

Sedangkan berdasarkan tabel 9 yang digunakan untuk melihat pengaruh variabel kepemilikan asing terhadap variabel CSR Disclosure, memiliki nilai koefisien regresi sebesar 0,038 dengan arah positif dan nilai sig 0,016 lebih kecil dari alpha 0,05 artinya variabel kepemilikan asing berpengaruh positif terhadap CSR Disclosure. Dengan demikian, dapat ditarik kesimpulan bahwa hipotesis $\mathrm{H} 2 \mathrm{~b}$ diterima.

\section{Pengujian $\mathrm{H}_{3}$}

Berdasarkan tabel 9 yang digunakan untuk melihat pengaruh CSR Expenditure terhadap CSR Disclosure, nilai koefisien regresi variabel CSR Expenditure sebesar 0,047 dengan arah positif dan nilai sig 0,000 lebih kecil dari alpha 0,05. Artinya, variabel CSR Expenditure berpengaruh positif terhadap CSR disclosure. Hal ini sesuai dengan hipotesis yang menyatakan bahwa variabel CSR Expenditure berpengaruh terhadap CSR Disclosure. Maka dapat tarik kesimpulan bahwa hipotesis H3 diterima.

\section{Uji Koefisien Determinasi (Adjusted R2)}

Berdasarkan tabel 8, model CSR Expenditure memiliki nilai koefisien determinasi (Adjusted R2) sebesar 0,012 artinya variabel independen yaitu media exposure dan kepemilikan asing dalam menjelaskan variasi perubahan variabel dependen yaitu CSR Expenditure sebesar 0,012 atau 1,2\% dan sisanya 98,8\% (100\% - 1,2\%) dijelaskan oleh faktor lain.

Sedangkan model CSR Disclosure yang ditunjukkan oleh tabel 9 memiliki nilai koefisien determinasi (Adjusted R2) sebesar 0,202 artinya varibel-variabel independen yaitu media exposure, kepemilikan asing dan CSR Expenditure dalam menjelaskan variasi perubahan variabel dependen yaitu CSR Disclosure sebesar 0,202 atau 20,2\% dan sisanya 79,8\% (100\% - 20,2\%) dijelaskan oleh faktor lain.

\section{Pengaruh Media Exposure Terhadap CSR Expenditure dan CSR Disclosure}

Berdasarkan hasil pengujian, variabel media exposure tidak berpengaruh terhadap CSR Expenditure. Oleh karena itu dapat diambil kesimpulan bahwa hipotesis H1a ditolak. Sedangkan untuk model CSR Disclosure, variabel media exposure berpengaruh terhadap CSR Disclosure. Hal ini menunjukkan bahwa hipotesis H1b diterima.

Adanya pengaruh media exposure terhadap pengungkapan Corporate Social Responsibility menunjukkan bahwa pemberitaan suatu perusahaan di media sangat penting. Karena perusahaan yang diberitakan di media akan mendapatkan sorotan dari pihak-pihak berkepentingan dan juga dari masyarakat. Pemberitaan suatu perusahaan di media akan memberikan tekanan kepada perusahaan itu sendiri untuk lebih memperhatikan masalah-masalah lingkungan dan juga permasalahan sosial yang sering terjadi di sekitar perusahaan itu berada. Pemberitaan di media juga akan mendorong perusahaan untuk melakukan pengungkapan yang lebih luas. Praktik pengungkapan CSR dapat menjelaskan konflik sosial dan lingkungan yang terjadi akibat kegiatan yang dilakukan perusahaan ditengah-tengah masyarakat (Chariri, 2008).

Meskipun pemberitaan di media akan mendorong perusahaan untuk lebih luas dalam melakukan pengungkapan CSR, namun tidak berarti bahwa perusahaan akan menggelontorkan dana yang lebih besar untuk melakukan kegiatan-kegiatan CSR nya. Perusahaan akan lebih memilih mengalokasikan biayanya untuk aktivitas lain yang akan memberikan keuntungan lebih besar bagi 
perusahaan. Karena perusahaan merupakan entitas bisnis yang akan terus mencari laba atau keuntungan demi kelangsungan hidup perusahaan dimasa mendatang. Penelitian ini sejalan dengan penelitian yang dilakukan oleh Plorensia dan Hardiningsih (2015), Alfarizi (2016) dan Handoko (2017) yang menemukan adanya pengaruh media exposure terhadap pengungkapan Corporate Social Responsibility.

\section{Pengaruh Kepemilikan Asing Terhadap CSR Expenditure dan CSR Disclosure}

Berdasarkan hasil pengujian pada model CSR Expenditure diketahui bahwa kepemilikan asing berpengaruh positif terhadap variabel CSR Expenditure. Sedangkan untuk model CSR Disclosure, kepemilikan asing juga berpengaruh positif terhadap variabel CSR Disclosure. Artinya kedua hipotesis tersebut diterima. Pengujian hipotesis H2a dan H2b tersebut mengindikasikan bahwa semakin tinggi kepemilikan saham asing maka tanggung jawab perusahaan untuk mengungkapkan CSR semakin luas. Kepemilikan asing merupakan jumlah saham yang dimiliki oleh individu atau lembaga yang berstatus luar negeri.

Menurut Puspitasari (2009) ada beberapa faktor yang menyebabkan perusahaan dengan kepemilikan saham asing mengungkapkan informasinya secara lebih luas. Pertama, praktik dan pengungkapan CSR lebih dahulu dikenal oleh perusahaan asing dibandingkan dengan negara ini. Kedua, pelatihan dalam bidang akuntansi didapatkan secara lebih baik oleh perusahan asing. Ketiga, sistem informasi yang dimiliki oleh perusahaan asing lebih efektif dan efisien sehingga dapat memenuhi kebutuhan informasi dari internal maupun eksternal. Selama ini pihak asing dianggap sebagai pihak yang concern terhadap isu sosial dan lingkungan, media yang sering digunakan oleh pihak asing untuk menunjukkan kepeduliaannya terhadap sosial dan lingkungan adalah melalui pengungkapan Corporate Social Responsibility.

Kepemilikan saham asing juga memiliki hubungan dengan CSR Expenditure, karena pemilik asing sangat memperhatikan isu sosial seperti hak asasi manusia, pendidikan dan tenaga kerja (Diana, 2016). Oleh karena itu, perusahaan dengan kepemilikan asing cenderung mengalokasikan biaya yang lebih tinggi untuk meningkatkan praktik CSR nya. Penelitian ini sejalan dengan penilitian yang dilakukan oleh Rustiarini (2011) dan Laksmitaningrum (2013) yang menyatakan kepemilikan saham asing berpengaruh positif terhadap pengungkapan Corporate Social Responsibility.

\section{Pengaruh CSR Expenditure Terhadap CSR Disclosure}

Berdasarkan hasil uji parsial menunjukkan bahwa CSR Expenditure berpengaruh positif terhadap CSR Disclosure. Maka dapat ditarik kesimpulan bahwa hipotesis H3 diterima. Banyaknya biaya CSR yang dikeluarkan oleh perusahaan dapat mencerminkan kegiatan CSR yang dilakukan. Semakin banyak jumlah CSR Expenditure maka semakin banyak pula kegiatan CSR dan pengungkapannya yang dilakukan oleh perusahaan (Febrianti, 2016).

Apabila dikaitkan dengan teori signalling, pengungkapan CSR akan memberikan sinyal kepada masyarakat bahwa perusahaan memiliki kinerja yang baik, sehingga masyarakat akan memberikan citra yang baik terhadap perusahaan. CSR Expenditure dan CSR Disclosure dapat dijadikan kegiatan jangka panjang dalam menarik investor dan masyarakat, karena dapat menjamin keberlangsungan hidup perusahaan dalam jangka waktu kedepan yang pada dasarnya menganut prinsip going concern.

\section{KETERBATASAN PENELITIAN}

Penelitian ini memiliki beberapa keterbatasan antara lain yaitu penelitian ini hanya menggunakan dua variabel independen yaitu media exposure dan kepemilikan asing, sehingga belum mencerminkan secara keseluruhan faktor-faktor yang mempengaruhi pengungkapan Corporate Social Responsibility. Selain itu, periode penelitian ini relatif pendek karena hanya menggunakan perusahaan periode tahun 2016 


\section{KESIMPULAN}

Penelitian ini bertujuan untuk melihat seberapa besar pengaruh dari variabel media exposure dan kepemilikan asing terhadap CSR Expenditure dan CSR Disclosure. Berdasarkan hasil analisis dan pengujian data dengan menggunakan sampel sebanyak 219 perusahaan seluruh sektor industri tahun 2016 yang terdaftar di Bursa Efek Indonesia, maka diambil kesimpulan pertama media exposure tidak berpengaruh terhadap CSR Expenditure. Kedua, Media exposure berpengaruh positif terhadap CSR Disclosure. Ketiga, Kepemilikan asing berpengaruh positif terhadap CSR Expenditure. Keempat, Kepemilikan asing berpengaruh positif terhadap CSR Disclosure. Kelima, CSR Expenditure berpengaruh positif terhadap CSR Disclosure.

\section{DAFTAR PUSTAKA}

Alfarizi, A. (2016). Pengaruh Media Exposure, Ukuran Perusahaan, Leverage dan Struktur Kepemilikan Saham Terhadap Pengungkapan Corporate Social Responsibility. Skripsi. Universitas Muhammadiyah Yogyakarta.

Barkemeyer, R. (2007). Legitimacy as a Key Driver and Determinant of CSR in Developing Countries. Paper for the 2007 Marie Curie Summer School on Earth System Governance. Amsterdam University of St Andrews.

Branco, M. C \& Rodrigues, L. L. (2008). Factors Influencing Social Responbilitiy Disclosure by Portugues Companies. Journal of Business Ethics. 83, 685-701.

Cahya, B. A. (2010). Analisis Pengaruh Kinerja Keuangan terhadap Tanggung Jawab Sosial Perusahaan. Skripsi. Fakultas Ekonomi Universitas Diponegoro.

Chariri, A. (2008). Kritik Sosial Atas Pemakaian Teori Dalam Penelitian Sosial dan Lingkungan. Jurnal Maksi, 8(2), 161-163.

Dela, F. M. (2014). Pengaruh Ukuran Perusahaan dan Kinerja Lingkungan Terhadap Pengungkapan Tanggung Jawab Sosial Perusahaan. Artikel Ilmiah Mahasiswa. Universitas Negeri Padang.

Ekowati, L. P. \& Anis, W. (2014). Pengaruh Profitabilitas, Likuiditas, Growth dan Media Exposure Terhadap Pengungkapan Tnggung Jawab Sosial Perusahaan. Prosiding Simposium Nasional Akuntansi XVII. Universitas Mataram. Lombok.

Fatoni, Rita, \& Kharis, R. (2016). Pengaruh Kepemilikan Publik, Return On Equity, Current Ratio, Umur Perusahaan dan Company Size Terhadap Pengungkapan Corporate Social Responbility. Jurnal of Accounting, 2 (2), 1-15.

Febrianti, D. (2016). Pengaruh Kinerja Keuangan Terhadap CSR Disclosure dan CSR Expenditure. Skripsi. Universitas Muhammadiyah Yogyakarta.

Ghozali, I. (2011). Aplikasi Analisis Multivariate dengan Program IBM SPSS19. Badan Penerbit Universitas Diponegoro, Semarang.

Handoko, R. (2011). Pengaruh Ukuran Perusahaan, Tipe Industri, Growth, dan Media Exposure Terhadap Pengungkapan Tanggung Jawab Sosial Perusahaan. Skripsi. Universitas Muhammadiyah Yogyakarta.

Herusetya, A. (2012). Pengaruh Karakteristik Perusahaan terhadap Luas Pengungkapan Corporate Social Responbility. Jurnal Akuntansi. Fakultas Ekonomi Universitas Indonesia. 1-17.

Laksmitaningrum, C. F. (2013). Analisis Pengaruh Karakeristik Perusahaan, Ukuran Dewan Komisaris dan Struktur Kepemilikan terhadap Pengungkapan CSR. Skripsi. Fakultas Ekonomi Universitas Diponegoro.

Mukti, A \& Kurnia. (2015). Pengaruh Karakteristik Perusahaan dan Ukuran Dewan Komisaris Terhadap Pengungkapan Corporate Social Responbility. Jurnal Ilmu dan Riset Akuntansi, $4(12), 1-17$.

Patten, D. M. (2002). Media Exposure, Public Policy Pressure, and Environmental Disclosure: An Examination of the Impact of Tri Data Availability. Accounting Forum 26(2), 152-171. 
Plorensia, W \& Pancawati, H. (2015). Pengaruh Agresivitas Pajak dan Media Eksplosure Terhadap Corporate Social Responbility. Dinamika Akuntansi, Keuangan dan Perbankan. 4-5.

Priantana, R. D. (2011). Pengaruh Struktur Good Corporate Governance terhadap Pengungkapan Corporate Social Responbility pada Perusahaan Keuangan yang Terdaftar di Bursa Efek Indonesia. Jurnal Telaah dan Riset Akuntansi.4(1), 1-13.

Putra, E. N. (2011). Pengaruh Karakteristik Perusahaan terhadap Pengungkapan Corporate Social Responbility. Journal of Business Finance and Accounting. 8-14.

Rahayu, P \& Indah, A. (2015). Pengaruh Kepemilikan Saham Publik, Profitabilitas dan Media Terhadap Pengungkapan Tanggung Jawab Sosial. Accounting Analysis Journal. 3-8.

Reverte, C. (2009). Determinants of Corporate Social Responbility Disclosure Ratings by Spanish Listed Firms. Journal of Business Ethics. 88, 351-366.

Rosiana, G. A., Gede J., \& Maria, M. R. (2013). Pengaruh Pengungkapan CSR Terhadap Nilai Perusahaan dengan Profitabilitas Sebagai Variabel Pemoderasi. E-Jurnal Akuntansi Universitas Udayana, 5(3), 3-5.

Rosmita, H. (2007). Faktor-faktor yang Mempengaruhi Pengungkapan Sosial (Social Disclosure) dalam Laporan Keuangan Tahunan Perusahaan Manufaktur di Bursa Efek Jakarta. Skripsi. Fakultas Ekonomi Universitas Islam Indonesia. Yogyakarta.

Rustiarini, N. W. (2011). Pengaruh Struktur Kepemilikan Saham Pada Pengungkapan Corporate Social Responbility. Jurnal Akuntansi, 6(1), 1-24.

Sari, R. A. (2012). Pengaruh Karakteristik Perusahaan Terhadap Corporate Social Responbility Disclosure pada Perusahaan Manufaktur yang Terdaftar di Bursa Efek Indonesia. Jurnal Nominal, 1(1), 2-4.

Sembiring, E. R. (2005). Karakteristik Perusahaan dan Pengungkapan Tanggung Jawab Sosial pada Perusahaan yang Tercatat di Bursa Efek Jakarta. Prosiding Simposium Nasional Akuntansi 7.

Siwi, Program CSR Tak Transparan PT Semen Tonasa Didemo Warga, http://bit.ly/218OLqp. Diakses tanggal 21 Mei 2017 pk 12.30 WIB.

Tamba, E. G. (2011). Pengaruh Strukur Kepemilikan Terhadap Pengungkapan Tanggung Jawab Sosial Perusahaan. Skripsi. Fakultas Ekonomi Universitas Diponegoro.

Wahyutama, N. R. (2016). Pengaruh Ukuran Perusahaan, Profitabilitas, Leverage dan Media Exposure Terhadap Corporate Social Responbility Disclosure. Artikel Ilmiah Mahasiswa. Universitas Jember.

Yuliani, N. (2014). Pengaruh Struktur Kepemilikan Saham dan Karakteristik Perusahaan Terhadap Pengungkapan Corporate Social Responbility pada Perusahaan Pertambangan yang Terdaftar di BEI Tahun 2011-2013. Jurnal Akuntasi. Universitas Maritim Raja Ali Haji. 510 . 